\title{
Dużo hałasu o nic? Uwagi o reformie modelu funkcjonowania Międzynarodowego Funduszu Walutowego ${ }^{1}$
}

\begin{abstract}
Streszczenie: W niniejszym artykule głównym celem będzie analiza efektów przekształceń modelu funkcjonowania MFW, zapoczątkowanych w 2006 r. w Singapurze, realizowanych w głównej mierze od 2010 roku i określanych jako najbardziej fundamentalna reorganizacja zarządzania w 65-letniej historii MFW i największe dotychczasowe przesunięcie wpływów na korzyść rynków wschodzących i państw rozwijających się. Artykuł ten, usytuowany w ramach instytucjonalnego nurtu badań nad globalnym zarządzaniem i wykorzystujący podejście badawcze, które określa się mianem krytycznej międzynarodowej ekonomii politycznej, będzie stanowił próbę odpowiedzi na pytanie czy reforma, polegająca na modyfikacji wielkości partycypacji poszczególnych państw w kapitale zakładowym Funduszu, czyli udziału w tzw. kwocie i wynikających z jej wielkości liczby głosów przypadających na państwa członkowskie, była nią $\mathrm{w}$ istocie, czy raczej stanowiła przykład dysfunkcjonalności global economic governance.
\end{abstract}

Słowa kluczowe: Międzynarodowy Fundusz Walutowy, global governance, gospodarki wschodzące, kwota

\section{Wprowadzenie}

ednym z wyznaczników głębokich przemian współczesnych stosunków międzynarodowych, jest wyłanianie się rynków lub gospodarek wschodzących (emerging markets, emerging economies) jako znaczącej siły inwestycyjnej i handlowej w skali globalnej. Wykorzystując zasoby ekonomiczne dla budowy znaczenia politycznego, gospodarki wschodzące podejmują działania zmierzające do wywarcia presji na państwach zachodnich w celu reformowania istniejących już struktur global governance, takich jak Organizacja Narodów Zjednoczonych (ONZ), Międzynarodowy Fundusz Walutowy (MFW), Bank Światowy (BŚ), w kierunku nadania im większej reprezentatywności. Aktywność państw takich jak Brazylia, Rosja, Indie, Chiny, Afryka Południowa, Turcja, Indonezja. Meksyk, przejawia się w tym zakresie dwutorowo. Po pierwsze, dążą one do instytucjonalizacji współpracy międzypaństwowej, która omija struktury będące centrami sieci instytucjonalnej kojarzonej z Zachodem. Za przykłady takich działań można uznać inicjatywy regionalne, takie jak: inicjatywa z Chiang Mai (Chiang Mai Initiative) ${ }^{2}$ czy Makroekonomiczne Biuro Badawcze ASEAN+3 (Macroeconomic Research Office, AMRO) $)^{3}$. Innym tego typu przedsięwzięciem, realizowanym w Ameryce Południowej, stał się Bank Południa (Banco del Sur) - utworzony jako regionalna instytucja bankowa

${ }^{1}$ Niniejszy artykuł został przygotowany w ramach grantu NCN „Globalne zarządzanie gospodarcze - aktorzy, obszary oddziaływania, interakcje”, nr rej. 2016/23/B/HS5/00118.

${ }^{2}$ Międzynarodowe porozumienie zawarte przez dziesięciu członków Stowarzyszenia Narodów Azji Południowo-Wschodniej (ASEAN), Chiny, Japonię i Koreę Południową.

${ }^{3}$ Powołane w Singapurze w kwietniu 2011 r. przez kraje ASEAN+3 (ASEAN, Chiny, Japonia i Korea) do monitorowania i analizy gospodarek regionalnych i wsparcia Chiang Mai Initiative. 
stanowiąca rodzaj alternatywy dla globalnego systemu pomocy finansowej/rozwojowej, opartego na działaniu tandemu MFW/BŚ. Bank Południa ustanowiono we wrześniu 2009 r. w celu udzielania pomocy finansowej dla państw Ameryki Południowej i wyposażono na starcie w środki w wysokości 20 mld USD. Za główny cel działania uznano zapewnienie pokrycia potrzeb finansowych tych państw Ameryki Południowej, które zdecydowały się na podjęcie kosztownych programów reform społecznych i gospodar$\mathrm{czych}^{4}$. W ramy tej ścieżki działania wpisała się też się aktywność grupy BRICS, która po raz pierwszy w składzie przywódców państw zebrała się w 2009 r. (Rewizorski, 2015, s. 58), niemal od razu stając się jedną z najważniejszych struktur XXI wieku (Lukov, 2012). Wyrazem postępującej instytucjonalizacji grupy, widocznej zwłaszcza w dziedzinie gospodarczej i finansowej (Larionova, Shelepov, 2015, s. 53), stało się doprowadzenie do uzgodnienia w 2013 r., przy okazji szczytu G-20 w St. Petersburgu, pozwalającego na utworzenie funduszu rezerwowego o wartości 100 mld USD, przeznaczonego na zapewnienie płynności finansowej oraz stabilizację gospodarek wschodzących (Xing, 2014, s. 13). Instrument ten potwierdzono zawarciem rok później, na szóstym szczycie BRICS w brazylijskiej Fortalezie, porozumienia o stworzeniu rezerwy środków finansowych na wypadek pojawienia się sytuacji kryzysowych (np. krótkoterminowych trudności w bilansie płatniczym, niestabilności finansowej itp.). Poszczególne państwa BRICS podzieliły między siebie ciężar finansowania rezerwy (Chiny - 41 mld USD, Brazylia, Rosja, Indie - po 18 mld USD, Afryka Południowa - 5 mld USD) (BRICS, 2014a). Nade wszystko instytucją zaprojektowaną w celu stworzenia alternatywy dla zachodniego systemu opierającego się na działalności MFW stał się Nowy Bank Rozwoju (New Development Bank), powołany do życia decyzją państw BRICS w 2014 r. Bank wyposażono w kapitał zakładowy o wartości 100 mld USD z przeznaczeniem na finansowanie projektów infrastrukturalnych w państwach grupy, innych gospodarkach wschodzących, a także państwach rozwijających się (BRICS, 2014b). Po drugie, gospodarki wschodzące wywierając presję na państwa zachodnie w celu reformowania istniejących już struktur global governance, starają się zwiększać wpływy w powstałych po zakończeniu II wojny światowej instytucjach systemu Bretton Woods - MFW i BŚ. Państwa niezachodnie posługując się kombinacją obu strategii działania i dysponując dużymi zasobami finansowymi oddziałują na wspomniane instytucje globalnego zarządzania gospodarczego za pośrednictwem zasobów kapitałowych. Oddziaływanie to ma na celu doprowadzić do jak najszerszego transferu siły decyzyjnej znajdującej się w rękach Zachodu i zakotwiczenia w świadomości liderów państw rozwiniętych przeświadczenia o zagrożeniu ich tradycyjnej, długotrwałej i wysoce zinstytucjonalizowanej dominacji w strukturach powojennego międzynarodowego ładu gospodarczego. Szukając efektywnych odpowiedzi na ekspansję gospodarek wschodzących Zachód stosuje metody oparte na rozciaganiu w czasie reform modelu funkcjonowania instytucji systemu Bretton Woods, przy jednoczesnym szukaniu sposobów na zabezpieczenie dalszej kontroli nad MFW i BŚ.

Głównym celem niniejszego artykułu będzie analiza efektów przekształceń modelu funkcjonowania MFW, zapoczątkowanych w 2006 r. w Singapurze, realizowanych

${ }^{4}$ Założycielami Banku Południa były: Argentyna, Boliwia, Brazylia, Ekwador, Paragwaj, Urugwaj, Wenezuela Por. MercoPress (2009), South American leaders sign agreement creating South Bank, 27 September 2009. http://en.mercopress.com/2009/09/27/south-american-leaders-sign-agreement-creating-south-bankBrazilian, 2.10.2016. 
w głównej mierze od 2010 roku i pompatycznie określonych przez byłego Dyrektora Generalnego MFW - Dominique Strauss-Kahna - jako „najbardziej fundamentalnej reorganizacji zarządzania w 65-letniej historii MFW i największego dotychczasowego przesunięcia wpływów na korzyść rynków wschodzących i państw rozwijających się" (IMF, 2010a). Z perspektywy lat, które upłynęły od "historycznych" uzgodnień, pomimo widocznego wzrostu udziału państw niezachodnich (non-West) w globalnym produkcie krajowym brutto (PKB), uznawanym za najważniejszy komponent siły głosu w MFW, realny wpływ wywierany przez non-West w Funduszu uległ tylko nieznacznemu zwiększeniu. Co więcej, część państw rozwiniętych reformy Funduszu nie postrzega w kategoriach strat, lecz zysków i to podwójnych. Po pierwsze, gospodarki wschodzące, łudząc się obietnicami zwiększenia znaczenia w MFW, zasiliły tę instytucję środkami finansowymi de facto rzucając jej koło ratunkowe pozwalające na przetrwanie najgorszego okresu w jej historii wywołanego konsekwencjami globalnego kryzysu finansowego. Po drugie, zapewniły czas niezbędny do tego, aby członkowie klubu G-7 dokonali ,przegrupowania" i wzmocnienia swojej pozycji w MFW. Powstają zatem pytania, czy realizowana w ślimaczym tempie reforma, polegająca na modyfikacji wielkości partycypacji poszczególnych państw w kapitale zakładowym Funduszu, czyli udziału w tzw. kwocie (ang. quota) i wynikających z jej wielkości liczby głosów przypadających na państwa członkowskie, była nią w istocie, czy raczej stanowiła przykład zinstytucjonalizowanej hipokryzji Zachodu i przykład dysfunkcjonalności global economic governance? Czy reforma modelu funkcjonowania MFW w kierunku docenienia roli rynków wschodzących to de facto dużo hałasu o nic? Czy może jest to udana propozycja złagodzenia sporu między zantagonizowanymi grupami państw grożącego zawieszeniem multilateralizmu, a nawet instytucjonalnym chaosem zarządzania w Funduszu?

Artykuł ten, usytuowany w ramach instytucjonalnego nurtu badań nad globalnym zarządzaniem ${ }^{5}$, będzie stanowił próbę nie tylko odpowiedzi na wyżej wskazane pytania, lecz także skonfrontowania oficjalnego przekazu wskazującego na znaczenie efektów reformy MFW, z faktycznymi jej rezultatami, chwalonymi przez transnarodowy establishment finansowy i personel Funduszu jako wielki sukces i ,fundamentalną reorganizację zarządzania". Pozwala na to posłużenie się podejściem badawczym, które określa się mianem krytycznej międzynarodowej ekonomii politycznej. Oferuje ono zastosowanie niekonwencjonalnej perspektywy na stosunki międzynarodowe. Będąc próbą otwarcia przestrzeni badawczej internacjologii (Strange, 1970), pozwala skupić uwagę na nierównościach systemu międzynarodowego i wynikających stąd strukturalnych hierarchii w dystrybucji nierówności siły/potęgi geoekonomicznej (Peterson, 2003, s. 3). Wielką zaletą tego ujęcia jest odejście od traktowania państwa jako „czarnej skrzynki” interesów narodowych wchodzących w interakcje zachodzące w ramach anarchicznych stosunków międzynarodowych. Krytyczna międzynarodowa ekonomia polityczna koncentruje się raczej na zrozumieniu złożoności systemowej, w jakiej przyszło państwom funkcjonować, a także udzieleniu odpowiedzi, jak doszło do ukształtowania się określonego porządku i jak się on zmienia.

${ }^{5}$ Por. T. J. Sinclair, Global Governance, Polity Press, Cambridge 2012; R. W. Cox, H. K. Jacobson The Anatomy of Influence: Decision Making in International Organization, Yale University Press, New Heaven 1973; R. O. Keohane, After Hegemony: Cooperation and Discord in the World Political Economy, Princeton University Press, New York 1984; R. W. Cox, T. J. Sinclair, Approaches to World Order, Cambridge University Press, Cambridge 1996. 


\section{„Kwota” jako kluczowy komponent reformy modelu funkcjonowania MFW}

Zmiany układu sił gospodarczych i politycznych, ukształtowanego bezpośrednio po II wojnie światowej, wyrażające się znaczącym wzrostem znaczenia gospodarek wschodzących, uznaje się za główne wyzwanie dla dotychczasowego modelu funkcjonowania MFW. W teorii Fundusz, uwzględniając rosnącą rolę rynków wschodzących, powinien zapraszać je do współpracy, dokonując przy tym stopniowej, acz zauważalnej, modyfikacji „skostniałej” struktury decyzyjnej. Wszystko po to aby w większej niż dotychczas mierze podejmować działania służące szybko rosnącej populacji państw słabo- i średniorozwiniętych, a także by zmniejszyć zjawisko „dysonansu realnego wpływu”. Mowa tutaj o rozdźwięku pomiędzy rosnącą rolą niektórych państw rozwijających się w międzynarodowych relacjach ekonomicznych a ich nadal relatywnie niewielkim wpływem na działalność MFW. Kluczową rolę w dramacie transformacji systemu zarządzania MFW odgrywają „kwoty”. Mają one zasadnicze znaczenie w określeniu relacji między danym państwem a Funduszem. Po pierwsze, kwota członkowska to ilość środków finansowych, wnoszonych przez dane państwo do MFW. Po drugie, udział w kwocie czy innymi słowy partycypacji poszczególnych państw w kapitale zakładowym Funduszu, przekłada się na liczbę głosów przypadających na każde z nich. Po trzecie, udział w kwocie wpływa na poziom dostępności środków finansowych oferowanych przez MFW. Po czwarte, kwota warunkuje udział w alokacji Specjalnych Praw Ciagnienia (ang. Special Drawing Rights - SDR) (IMF, 2008, s. 1). W MFW stosowany jest system proporcjonalny (ważony) w odniesieniu do podziału głosów na forum instytucji. W zamierzeniach powinien odzwierciedlać potencjał ekonomiczny poszczególnych państw. Zgodnie z zapisami sekcji 5 art. XII Statutu, oznacza to, iż każde państwo członkowskie dysponuje 750. głosami podstawowymi oraz także głosami dodatkowymi, których liczba uzależniona jest od wysokości wpłat w SDR do kapitału zakładowego (jest to zatem udział w kwocie). Każde 100000 SDR daje kolejny głos (IMF, 2016a). Dodatkowe wpłaty zależą w praktyce od wielkości udziału danego państwa w ogólnej kwocie MFW (który jest wyznaczany i przydzielany przez Fundusz poszczególnym członkom). Warto w tym miejscu dodać, iż przydział kwoty ma również związek z polityką kredytową MFW. Konkretny jej poziom rodzi istotne skutki finansowe związane z możliwością pozyskania przez dane państwo, proporcjonalnie do jej ustalonej wielkości i faktycznie dokonanej wpłaty, środków finansowych z zasobów Funduszu (Wróblewski, 2016, s. 40). Dystrybucja kwot MFW ma w zamierzeniu odzwierciedlać relatywną wagę i rolę państw członkowskich tej organizacji w gospodarce światowej. W praktyce jednak udział państw członkowskich w ogólnej kwocie MFW jest zmienny i niedokładnie odzwierciedla realia ekonomiczne. Kwota jest kalkulowana za pomocą specjalnych algorytmów zwanych formułami (ang. quota formula), które są okresowo modyfikowane przez MFW. Przyjęta formuła podziału kwoty opiera się na średniej ważonej obejmującej kilka składników. W wersji z września 2016 roku zalicza się do nich: PKB (50\%), otwartość gospodarki $(30 \%)$, różnorodność gospodarczą (15\%) oraz wysokość rezerw międzynarodowych (5\%). PKB mierzy się w oparciu o PKB w cenach rynkowych $(60 \%)$ oraz Parytet Siły Nabywczej (PPP) - 40\%. Formuła zawiera także czynnik kompensacyjny, który redukuje rozproszenie udziału w kwocie między państwami członkowskimi Funduszu (IMF, 2016b). Obowiązujący algorytm podziału kwoty można przedstawić w postaci wzoru: 


$$
C Q S=(0,5 \cdot Y+0,3 \cdot O+0,15 \cdot V+0,05 \cdot R)^{\mathrm{k}},
$$

gdzie: CQS (calculated quota share) - kalkulacja udziału w kwocie;

$Y$ - PKB 60/40 oparty w 60\% na cenach rynkowych oraz w 40\% na Parytecie Siły Nabywczej (PPP);

$O$-stopień otwartości gospodarki, na który składa się przeciętna roczna suma bieżących płatności i przychodów (towary, usługi, transfery) za okres pięciu lat;

$V$-zmienność bieżących przychodów i przepływów kapitałowych netto (mierzonych jako standardowe odchylenie od centralnego trzyletniego trendu w okresie trzynastu lat);

$R$ - średni poziom rezerw w okresie dwunastu miesięcy (operacji walutowych, transz rezerwowych w MFW, zasobów SDR, złota monetarnego);

$K$ - czynnik kompensacyjny wynoszący 0,95 .

Kwoty denominowane są w SDR, jednostce księgowej, czy też „walucie” MFW. Po 14. Ogólnym Przeglądzie Kwoty w 2010 roku (ang. 14th General Review of Quotas), którego ustalenia zostały implementowane 26 stycznia 2016 roku, kwoty 189. państw MFW (wliczając w to nowych nowo przyjętych członków MFW - Kosowo, Tuvalu i Sudan Południowy) zwiększono z poziomu 238,4 mld SDR (ok. 329 mld USD) do poziomu 477 mld SDR (ok 659 mld USD), co pozwoliło na transfer siły decyzyjnej w kierunku niektórych gospodarek wschodzących i państw rozwijających się na czele z Chinami, Indiami i Brazylią. Według stanu z 26 kwietnia 2017 roku kapitał zakładowy Funduszu wynosi 475383 mln SDR (IMF, 2017a). Największym udziałowcem w kapitale zakładowym Funduszu są Stany Zjednoczone Ameryki, których kwota denominowana w SDR wynosi 82,99 mld (ok. 115 mld USD), najmniejszy udział posiada zaś Tuvalu z kwotą w wysokości 2,5 $\mathrm{mln} \operatorname{SDR}(3,5 \mathrm{mln}$ USD).

\section{W poszukiwaniu przełomu - reforma MFW i jej ocena}

Jak już wspomniano, dystrybucja kwot MFW, a co za tym idzie liczba głosów, którymi dysponują poszczególne państwa członkowskie organizacji, ma w zamierzeniu odzwierciedlać ich rolę w gospodarce światowej. W praktyce jednak udział państw członkowskich w ogólnej kwocie MFW niedokładnie odzwierciedla realia ekonomiczne. Kwestia ta od ponad 20. lat jest przedmiotem krytyki kierowanej pod adresem organizacji przez państwa rozwijające się. Wskazując na rosnący udział ich gospodarek w światowym PKB domagają się aktualizacji struktury zarządczej Funduszu i redystrybucji głosów na forum organizacji. Mechanizmem pozwalającym na rekonfigurację siły głosów w MFW, zgodnie z postanowieniami art. III sekcja 2 pkt a statutu MFW, są tzW. ogólne przeglądy kwot. Przeprowadza je Rada Gubernatorów Funduszu w odstępie nieprzekraczającym pięciu lat. W punkcie c statut MFW wprowadza zastrzeżenie formalne, zgodnie z którym wszelkie takie zmiany mogą wejść w życie jedynie po uzyskaniu aprobaty państw członkowskich reprezentujących co najmniej 85\% całkowitej liczby głosów na forum organizacji (IMF, 2016a). Co więcej, zmiany, zgodnie z art. XXVIII statutu, musi poprzeć co najmniej 3/5 państw członkowskich MFW (113 ze 189 państw). Kluczowe w tym zakre- 
sie jest stanowisko Stanów Zjednoczonych Ameryki, które dysponując pulą ponad 16\% głosów mają de facto prawo weta w przypadku wszelkich zmian nieodpowiadających ich interesom. Praktyka kolejnych ogólnych przeglądów wykazała, że o ile pozyskanie odpowiedniej liczby państw dla zmian było relatywnie łatwe do osiagnięcia, o tyle znacznie trudniej było uzyskać wymagany odsetek głosów. Zwykle głównym „,hamulcowym" zmian w MFW były Stany Zjednoczone. Kongres USA z dużą nieufnością zwykł podchodzić do jakichkolwiek aktualizacji mechanizmu zarządczego Funduszu z obawy, iż: 1) proponowane zmiany mogłyby pozbawić USA uprzywilejowanej pozycji w MFW; 2) narażałyby amerykańskich sojuszników skupionych w grupie OECD na ryzyko relatywnego osłabienia ich pozycji względem gospodarek wschodzących.

Koncentrując się na szczególnej roli USA w zakresie reformy modelu funkcjonowania MFW warto poczynić dodatkowe uwagi. Praktyka 14. dotychczasowych ogólnych przeglądów pokazuje, że siła Waszyngtonu w MFW znacznie wykracza poza prawo weta. Często wskazuje się na argument historyczny wynikający z faktu, że MFW, utworzony obok Banku Światowego w 1944 roku jako instytucja systemu Bretton Woods, został uformowany w warunkach supremacji ekonomicznej USA, wykorzystujących obie instytucje do własnych celów. Pomimo wzrostu znaczenia Wspólnot Europejskich, Chin i innych państw członkowskich Funduszu, USA zachowały uprzywilejowaną pozycję w strukturach Bretton Woods. Nie zmienia tego faktu nieformalne, pozastatutowe uzgodnienie, zgodnie z którym dyrektor generalny Funduszu jest Europejczykiem a prezes Banku Światowego jest wybierany spośród obywateli Stanów Zjednoczonych Ameryki. Pomimo pozorów równego podziału - „augustem” - czyli faktycznym rządcą Funduszu jest Waszyngton, który pozostawia Brukseli znacznie skromniejszą rolę „cezara”, czyli współrządcy - pomocnika i młodszego kolegi. Warunkiem objęcia przez Europejczyka stanowiska w Funduszu jest jego akceptacja przez Departament Skarbu USA. Przykład braku poparcia USA dla kandydatury niemieckiego wiceministra finansów Caio Koch-Wesera na stanowisko dyrektora generalnego MFW w 2000 r., będący przyczyną jego porażki w wyborach, dobitnie świadczy o przewadze ,amerykańskiego augusta” nad „europejskim cezarem” w MFW6. Amerykański Department Skarbu, mając do dyspozycji prawo weta w MFW i wsparcie ze strony Europy, wywiera decydujący wpływ na kształt polityki adresowanej do pomocobiorców. Jako że między USA a UE wątpliwości w odniesieniu do polityki pożyczkowej Funduszu wobec państw niezachodnich zachodzą stosunkowo rzadko,

${ }^{6}$ Wspominany przykład odnosi się do wyborów z 2000 r. Po zakończeniu pełnienia funkcji przez wieloletniego dyrektora generalnego Funduszu Michela Camdessusa, Niemcy zaproponowały na wakujące stanowisko kandydaturę wieloletniego pracownika Banku Światowego i wiceministra finansów Caio Koch-Wesera. Propozycję wyraźnie poparł ówczesny kanclerz Niemiec Gerhard Schröder, który zorganizował Koch-Weserowi 4-miesięczną kampanię wyborczą. Niemiecka kandydatura spotkała się jednak z chłodnym przyjęciem w USA i Europie. Koch-Weser w głosowaniu uzyskał 43\% głosów, co było bardzo słabym wynikiem zważywszy na 37\% całości głosów, którymi dysponowały w Funduszu państwa UE. Kontrkandydat Koch-Wesera, Stanley Fischer, popierany przez koalicję państw arabskich i afrykańskich uzyskał 12\%, zaś trzeci z kandydatów - Eisuke Sakakibara - były urzędnik w japońskim ministerstwie finansów, dostał 9\% głosów. Por. J. Kahn (2000), I.M.F. Directors Fail to Rally Around Any New Leader in Poll, ,The New York Times” z 3 marca 2000, http:// www.nytimes.com/2000/03/03/business/imf-directors-fail-to-rally-around-any-new-leader-in-poll. html, 2.03.2017. 
Waszyngton nawet w obliczu wzmagającej się presji ze strony rynków wschodzących utrzymuje dominującą pozycję w MFW.

Układ dwuwładzy, oparty na współpracy ,,augusta” i ,,cezara” w Funduszu jest coraz silniej kontestowany przez gospodarki wschodzące, posiadające coraz większy udział w gospodarce światowej, zwłaszcza że ta ostatnia uległa znacznym przeobrażeniom od czasu kryzysu 2008+. Ich skalę dostrzega sam MFW wskazując, że Chiny, główny eksponent argumentu o konieczności reformy Funduszu, między 2008 a 2016 rokem zwiększyły swoją gospodarkę o $78 \%$, podczas gdy w tym samym czasie wzrost gospodarczy w Europie był ledwo dostrzegalny (IMF, 2016c). Intensywna krytyka, a także szereg poważnych błędów, które zachwiały pozycją MFW począwszy do kryzysu azjatyckiego w 1997 r., związanego $\mathrm{z}$ atakiem spekulacyjnym na tajlandziego bahta, i nieadekwatną odpowiedzią Funduszu na turbulencje finansowe na Filipinach, w Malezji, Singapurze, Indonezji i Korei Południowej, zmusily MFW do zainicjowania reformy modelu funkcjonowania w celu powstrzymania erozji wiarygodności organizacji ${ }^{7}$. Pierwsze próby zmierzające do większego zaangażowania „rynków wschodzących” w proces podejmowania decyzji przez Fundusz oraz rozszerzenia ich wpływu na jego działalność operacyjną pojawiły się w 1999 r. Proces ten nabrał jednak tempa we wrześniu 2006 r. w Singapurze, kiedy państwa członkowskie na corocznym spotkaniu MFW przyjęły pakiet reform organizacji. Jego realizację zaplanowano na 2,5 roku (IMF, 2006). W pierwszym etapie zakładał on realizację kilku celów: 1) podniesienie wielkości kwoty dla najbardziej niedoreprezentowanych członków MFW - Chin, Korei, Meksyku i Turcji; 2) wprowadzenie nowej, uproszczonej formuły kwotowej; 3) dalsze podnoszenie wielkości kwot w oparciu o nową formułę 4) potrojenie liczby głosów podstawowych posiadanych przez każdego członka Funduszu (z 250 do 750); 5) przyznanie dwóch miejsc w radzie dyrektorów wykonawczych państwom niedoreprezentowanym. O ile pierwszy z celów został implementowany w 2006 roku, kolejne cele pakietu reform zostały zatwierdzone przez Radę Wykonawczą Funduszu 28 marca 2008 roku. Reforma, określana także jako „2008 Quota and Voice Reforms” i stanowiąca drugi etap zmian zapoczątkowanych w Singapurze (2006), weszła w życie 3 marca 2011 r., po zatwierdzeniu jej przez 3/5 członków MFW (117 państw), reprezentujących 85\% całkowitej liczby głosów na forum organizacji. W wyniku reformy: 1) dokonano przesunięcia w zakresie udziałów w całkowitej kwocie MFW i zmian liczby głosów na korzyść 54. państw członkowskich na

${ }^{7}$ Warto zauważyć, że azjatycki kryzys finansowy często bywa określany jako „kryzys Międzynarodowego Funduszu Walutowego". W sytuacji deprecjacji wschodnioazjatyckich walut o $30-50 \%$, załamania konsumpcji i inwestycji, spadku cen akcji i nieruchomości, a nadto gwałtownego wzrostu bezrobocia MFW zareagował zawarciem porozumień z Tajlandią, Indonezją i Koreą Południową, które przewidywały udzielenie tym państwom pomocy finansowej o łącznej sumie około 110 mld dolarów. Wszyscy pomocobiorcy zostali zmuszeni do spełnienia bardzo rygorystycznych warunków, tj. do zwiększenia dyscypliny budżetowej, znacznego podwyższenia stóp procentowych, zwiększenia ilości rezerw walutowych oraz przeprowadzenia gruntownych reform strukturalnych. Jednakże te środki, zwłaszcza podnoszenie stóp procentowych, nie zahamowały odpływu kapitału. Co więcej, doprowadziły do utraty płynności finansowej przez wiele krajowych firm, których nie było stać na zaciąganie kredytów obrotowych. To z kolei skutkowało falą bankructw, zwiększeniem ilości niespłaconych pożyczek i dalszym ograniczeniem kredytu w gospodarce. Warto zauważyć, że programy pomocowe MFW odrzuciła Malezja, która oskarżając Fundusz o przyczynienie się do rozlewania się niestabilności finansowej w Azji, skupiła się na rozbudowie infrastruktury oraz reglamentacji obrotów kapitałowych, co pozwoliło bankowi centralnemu tego państwa odzyskać kontrolę nad kursem walutowym. 
kwotę 20,8 mld SDR (ok. 32,7 mld USD); 2) zwiększono partycypację w Funduszu państw o niskim dochodzie poprzez potrojenie liczby głosów podstawowych każdego z jego członków; 3) wprowadzono mechanizm utrzymywania stałej proporcji głosów podstawowych do całkowitej liczby głosów w MFW (IMF, 2011a). Poniżej w tabeli 1 ukazano zmiany udziałów w kwocie oraz posiadaną liczbę głosów przez państwa członkowskie MFW przed przyjęciem pakietu singapurskiego (stan na 17 września 2006 r.) oraz po wejściu w życie drugiego etapu pakietu - 2008 Quota and Voice Reforms (stan na 3 marca 2011 r.), z podziałem na państwa, które najwięcej zyskały i najwięcej straciły w wyniku reformy.

Tabela 1

Podział kwoty oraz liczba głosów w Radzie Wykonawezej MFW wybranych państw członkowskich przed i po wprowadzeniu zmian wynikających z pakietu singapurskiego (w \%)

\begin{tabular}{|c|c|c|c|c|c|c|c|c|c|}
\hline \multicolumn{5}{|c|}{$\overline{\text { Przydzial (kwota) }}$} & \multicolumn{5}{|c|}{ Glosy } \\
\hline \multicolumn{5}{|c|}{ Państwa, które najwięcej zyskały } & \multicolumn{5}{|c|}{ Państwa, które najwięcej zyskały } \\
\hline Ip. & państwo & $\begin{array}{c}\text { stan na } \\
17.09 .2006\end{array}$ & zm. & $\begin{array}{c}\text { stan na } \\
\text { 3.03.2011 }\end{array}$ & Ip. & państwo & \begin{tabular}{|c|} 
stan na \\
17.09 .2006
\end{tabular} & zm. & $\begin{array}{c}\text { stan na } \\
3.03 .2011\end{array}$ \\
\hline 1. & Chiny & 2,98 & $+1,01$ & 3,99 & 1. & Chiny & 2,92 & +0.88 & 3,80 \\
\hline 2. & Korea Płd. & 0,76 & $+0,65$ & 1,41 & 2. & Korea Płd. & 0,76 & $+0,60$ & 1.36 \\
\hline 3. & Indie & 1,94 & $+0,50$ & 2,44 & 3. & Indie & 1,91 & $+0,41$ & 2.33 \\
\hline 4. & Brazylia & 1,42 & $+0,36$ & 1,78 & 4. & Brazylia & 1,40 & $+0,31$ & 1,71 \\
\hline 5. & Japonia & 6,22 & $+0,34$ & 6,56 & 5. & Meksyk & 1,19 & $+0,27$ & 1,46 \\
\hline 6. & Meksyk & 1,21 & $+0,31$ & 1,52 & 6. & Hiszpania & 1,40 & $+0,22$ & 1,62 \\
\hline 7. & USA & 17,38 & $+0,28$ & 17,66 & 7. & Singapur & 0,40 & $+0,18$ & 0,58 \\
\hline 8. & Hiszpania & 1,42 & $+0,26$ & 1,68 & 8. & Turcja & 0,45 & $+0,15$ & 0,60 \\
\hline 9. & Singapur & 0,40 & $+0,19$ & 0,59 & 9. & Irlandia & 0,39 & $+0,13$ & 0,52 \\
\hline 10. & Turcja & 0,45 & $+0,16$ & 0,61 & 10. & Japonia & 6,10 & $+0,12$ & 6,22 \\
\hline \multicolumn{5}{|c|}{ Państwa, które najwięcej stracily } & \multicolumn{5}{|c|}{ Państwa, które najwięcej stracily } \\
\hline Ip. & państwo & \begin{tabular}{|c|} 
stan na \\
17.09 .2006 \\
\end{tabular} & zm. & $\begin{array}{c}\text { stan na } \\
\text { 3.03.2011 } \\
\end{array}$ & Ip. & państwo & \begin{tabular}{|c|} 
stan na \\
17.09 .2006 \\
\end{tabular} & zm. & $\begin{array}{c}\text { stan na } \\
\text { 3.03.2011 } \\
\end{array}$ \\
\hline 1. & Wlk. Brytania & 5,02 & $-0,52$ & 4,50 & 1. & Wlk. Brytania & 4,92 & $-0,64$ & 4,28 \\
\hline 2. & Francja & 5,02 & $-0,52$ & 4,50 & 2. & Francja & 4,92 & $-0,64$ & 4,28 \\
\hline 3. & $\begin{array}{ll}\text { Arabia } & \text { Saudyj- } \\
\text { ska }\end{array}$ & 3,26 & $-0,34$ & 2,92 & 3. & $\begin{array}{l}\text { Arabia Saudyj- } \\
\text { ska }\end{array}$ & 3,21 & $-0,42$ & 2,79 \\
\hline 4. & Kanada & 2,98 & $-0,31$ & 2,67 & 4. & Kanada & 2,92 & $-0,37$ & 2,55 \\
\hline 5. & Rosja & 2,78 & $-0,29$ & 2,49 & 5. & Rosja & 2,73 & $-0,35$ & 2,38 \\
\hline 6. & Holandia & 2,41 & $-0,25$ & 2,16 & 6. & Holandia & 2,37 & $-0,30$ & 2,07 \\
\hline 7. & Belgia & 2,15 & $-0,22$ & 1,93 & 7. & USA & 17,02 & $-0,31$ & 16,71 \\
\hline 8. & Szwajcaria & 1,61 & $-0,16$ & 1,45 & 8. & Belgia & 2,12 & $-0,27$ & 1,85 \\
\hline 9. & Australia & 1,51 & $-0,16$ & 1,35 & 9. & Szwajcaria & 1,59 & $-0,20$ & 1,39 \\
\hline 10. & Wenezuela & 1,24 & $-0,13$ & 1,11 & 10. & Australia & 1,49 & $-0,18$ & 1,31 \\
\hline
\end{tabular}

Źródło: Opracowanie własne na podstawie: IMF (2011b), Quota and Voting Shares Before and After Implementation of Reforms Agreed in 2008 and 2010, Washington D.C., http://www.imf.org/external/np/sec/ $\mathrm{pr} / 2011 / \mathrm{pdfs} /$ quota_tbl.pdf, 23.04.2017.

Rezultaty reformy tylko częściowo spełniły oczekiwania Chin, Korei, Meksyku i Turcji. Spośród państw rozwijających się umiarkowane korzyści odniosły także Indie i Brazylia. Z kolei Rosja i Afryka Południowa straciły na reformie. Biorąc pod uwagę dość ograniczone zyski po stronie gospodarek wschodzących i stosunkowo nieznaczne straty w zakresie udziału w kwocie MFW i liczbie głosów po stronie państw rozwiniętych, w tym zwłaszcza 
uczestniczących w klubie G-7, trudno uznać „, 2008 Quota and Voice Reforms” za reformę udana. Wniosek ten potwierdzają dane zaczerpnięte z kalkulacji MFW i przedstawione na wykresach 1 i 2. Obrazują one jedynie nieznaczną zmianę rozkładu kwoty i głosów między państwami rozwiniętymi a rozwijającymi się w latach 2006-2011.

\section{Wykres 1. Podzial kwoty między państwami rozwiniętymi i rozwijającymi się w MFW} przed i po wprowadzeniu zmian wynikających z pakietu singapurskiego ( $w$ \% calości)

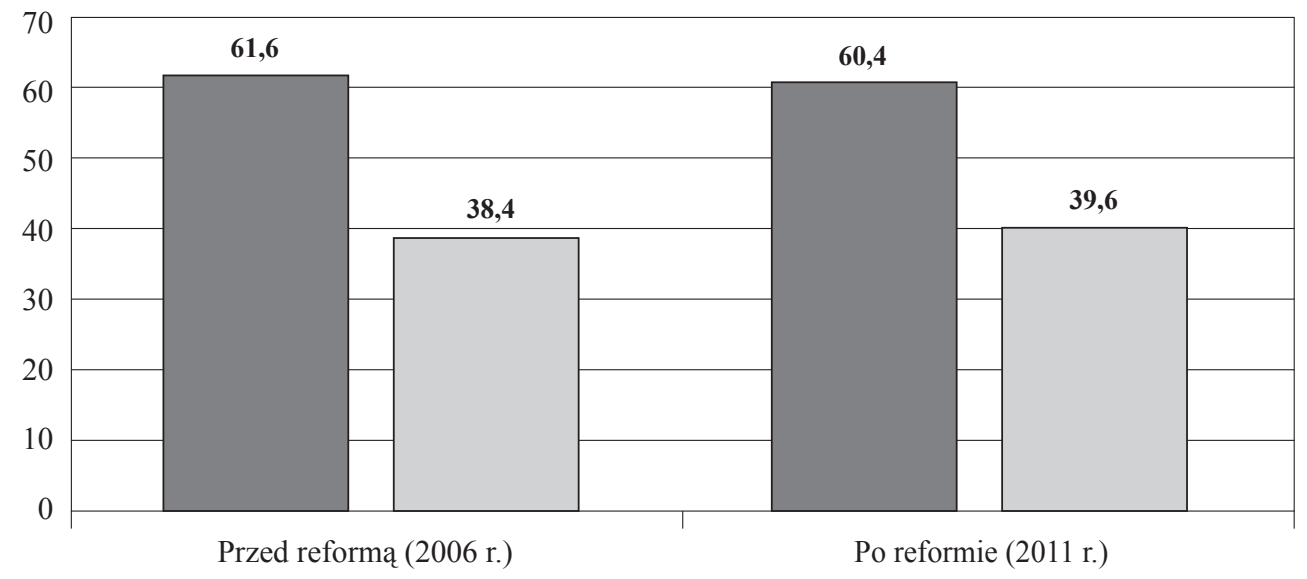

$\square$ Państwa rozwinięte $\square$ Państwa rozwijające się

Źródło: Opracowanie własne na podstawie: IMF (2011b), Quota and Voting Shares Before and After Implementation of Reforms Agreed in 2008 and 2010, Washington D.C., http://www.imf.org/external/np/sec/ pr/2011/pdfs/quota_tbl.pdf, 23.04.2017.

Wykres 2. Podzial głosów między państwami rozwiniętymi i rozwijającymi się w MFW przed i po wprowadzeniu zmian wynikających z pakietu singapurskiego (w \% całości)

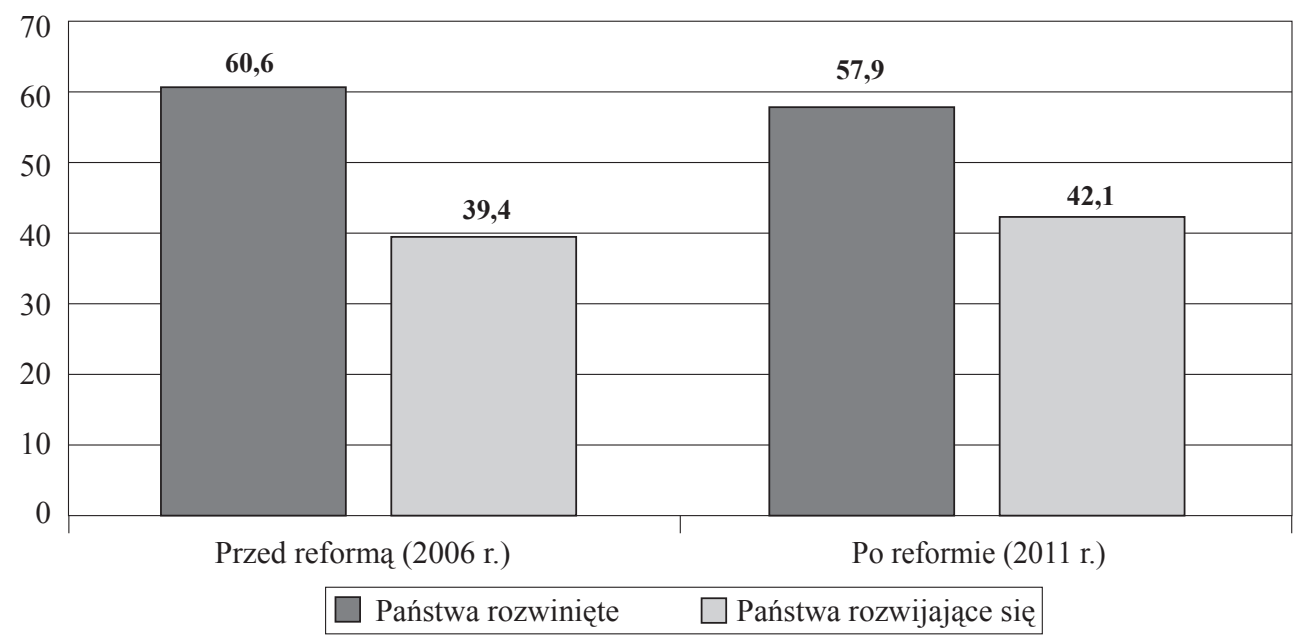

Źródło: Opracowanie własne na podstawie: IMF (2011b), Quota and Voting Shares Before and After Implementation of Reforms Agreed in 2008 and 2010, http://www.imf.org/external/np/sec/pr/2011/pdfs/quota_tbl. pdf, 23.04.2017. 
Rozczarowanie postępami ,2008 Quota and Voice Reforms”, a także nasilająca się presja ze strony gospodarek wschodzących, dążących do jak najszybszego zwiększenia siły decyzyjnej w Funduszu, wpłynęły w głównej mierze na kontynuowanie procesu reform określanego przez MFW jako „2010 Quota and Voice Reforms”. Należy zauważyć, że na podjęcie decyzji przez Radę Wykonawczą Funduszu dotyczącej aktualizacji struktury zarządczej i redystrybucji głosów na forum organizacji na rzecz państw zaliczanych przez MFW do grupy rynków wschodzących i państw rozwijających się (emerging markets and developing countries, EMDCs) wpłynęły szczególne okoliczności. Wybuch globalnego kryzysu finansowego wywołał potrzebę znalezienia środków pożyczkowych, którymi zachodni udziałowcy MFW nie dysponowali. Stąd też naturalne stało się zwrócenie w stronę rynków wschodzących, domagających się w zamian zwiększenia ich roli w globalnym zarządzaniu gospodarczym. Rozpoczęła się ,pełzająca” reforma instytucji Bretton Woods określona jako „2010 Quota and Voice Reforms”. Optymistyczny, choć przedwczesny, wyraz tym zmianom dała m.in. Ngaire Woods zauważając, że największymi „zwycięzcami” stały się Chiny, Indie, Brazylia, Singapur, Turcja i Meksyk, i to pomimo, że przesunięcia na korzyść tych państw były stosunkowo nieznaczne (Woods, 2010, s. 56). W rzeczywistości każdy punkt negocjacyjny procesu quota and vote stanowił pole niekończących się negacjacji z wysokouprzemysłowionymi członkami G-7, wśród których stanowisko prezentowane przez państwa europejskie (Wielka Brytania, Francja, Niemcy i Włochy - E-4) zostało, przez państwa spoza bloku zachodniego, poddane daleko idącej krytyce. Grupie E-4 zarzucono nadreprezentację w zakresie siły głosów i liczby stanowisk wykonawczych w instytucjach Bretton Woods. Długotrwałe spory wokół wyżej wskazanych kwestii, które rozgorzały po zakończeniu szczytu G-20 w Pittsburghu (wrzesień 2009), zostały częściowo złagodzone 23 października $2010 \mathrm{r}$. na spotkaniu ministrów finansów i prezesów banków centralnych w koreańskim Gyeongju. Miało ono charakter przygotowawczy przed szczytem G-20 w Seulu zaplanowanym na listopad $2010 \mathrm{r}$. Zawarte tam porozumienie, w sprawie reformy zarządzania instytucjami Bretton Woods (zwłaszcza w MFW) zakładało: 1) zwiększenie kwot udziałowych i głosów w MFW o 6,2\% na korzyść państw niedoreprezentowanych (zwłaszcza Brazylii, Chin, Rosji, Indii) ze zobowiązaniem do formalnego zatwierdzenia zmian w październiku 2012 r.; 2) rozszerzenie reprezentacji państw wschodzących i rozwijających się w systemie głosów ważonych MFW dzięki jego przeglądowi zaplanowanemu na styczeń 2014 r.; 3) oddanie przez państwa europejskie dwóch miejsc w Funduszu na rzecz państw niedoreprezentowanych (Menkes, 2010, s. 379). Ostatecznie 5 listopada 2010 roku Rada Wykonawcza Funduszu przyjęła założenia pakietu reform, zakładającego m.in.: 1) ponad $6 \%$ transfer udziałów w kapitale zakładowym Funduszu z państw nadreprezentowanych do niedoreprezentowanych; 2) ponad 6\% wzrost udziałów w kwocie państw EMDC; 3) dokonanie przeglądu nowej formuły nie później niż do stycznia 2013 roku; 4) zakończenie 15. Ogólnego Przeglądu Kwoty w styczniu 2014 r. (IMF, 2010b, s. 2-6).

Pakiet zmian ,2010 Quota and Voice Reforms” miał związek z 14. Ogólnym Przeglądem Kwoty z 2010 roku (ang. 14th General Review of Quotas), a także akcesją kilku nowych państw do MFW (m.in. członkostwo w organizacji uzyskały Kosowo, Tuvalu i Sudan Południowy). Zapowiadany transfer większej aniżeli dotychczas części kwoty do państw rozwijających się miał doprowadzić do szerszej reprezentacji rynków wscho- 
dzących w procesach decyzyjnych MFW (Wróblewski, 2016, s. 39), wzmocnienia wiarygodności, efektywności i legitymizacji Funduszu, stanowiąc przy tym w ocenie jej ówczesnego dyrektora - Dominique Strauss-Kahna - ,najbardziej fundamentalną reorganizację zarządzania w 65-letniej historii MFW" (IMF, 2010a). Rzeczywistą ceną za nowy pakiet dla jego beneficjentów było przyjęcie w czerwcu 2012 roku, podczas szczytu G-20 w meksykańskim Los Cabos, zobowiązania dokapitalizowania MFW środkami finansowymi mającymi stanowić podstawę „zapory ogniowej” (firewall), zaprojektowanej w celu niedopuszczenia do rozszerzenia się kryzysu finansowego ze strefy euro na rynki globalne. Chiny zadeklarowały przekazanie 43 mld USD, Brazylia i Rosja - 10 mld, a Afryka Południowa - 2 mld (Fin24, 2012). Zobowiązania te gospodarki wschodzące potraktowały jako inwestycję na poczet korzystnych dla nich reform zwiększających siłę głosu w MFW. Zwrot inwestycji nastapił jednak z dużym opóźnieniem. Warunki do wprowadzenia w życie zmian (3/5 liczby państw członkowskich Funduszu i nie mniej niż 85\% całkowitej liczby głosów) zostały spełnione dopiero w grudniu 2015 r. $^{8}$ Przyjęcie zmian nastąpiło formalnie 21 stycznia 2016 r. Zgodę na reformę modelu funkcjonowania MFW wyraziło wówczas 149. państw członkowskich reprezentujących $94,04 \%$ głosów.

W wyniku reformy:

- kwoty wszystkich państw członkowskich uległy zwiększeniu w wyniku podwojenia kapitału zakładowego Funduszu z poziomu 238,5 mld SDR (tj. ok. 329 mld USD), do poziomu 477 mld SDR (tj. ok. 659 mld USD);

- więcej niż 6\% udziału w kwocie MFW uzyskały gospodarki wschodzące i państwa rozwijające się;

- cztery rynki wschodzące (Chiny, Brazylia, Indie i Rosja) zaliczono do grona dziesięciu najważniejszych członków MFW (obok USA, Japonii oraz państw grupy E-4);

- potwierdzono obowiązywanie zasady o ochronie wielkości udziałów w kwocie i liczby głosów najbiedniejszych państw członkowskich MFW;

- po raz pierwszy wprowadzono zasadę, zgodnie z którą Rada Wykonawcza MFW składać się będzie z wybieralnych dyrektorów wykonawczych, co zakończy praktykę wskazywania dyrektorów wykonawczych przez pięć państw z najwyższymi udziałami w kwocie;

- wysokouprzemysłowione państwa europejskie zobowiązały się do ograniczenia liczby reprezentantów w Radzie Wykonawczej MFW o dwa miejsca (IMF, 2015).

Należy zauważyć, że na dzień 26 kwietnia 2017 r. zwiększenie swojego udziału w kwocie, w ramach zaaprobowanych zmian wynikających z 14. Ogólnego Przeglądu Kwoty, zaakceptowało 184. członków MFW (na 189 ogółem), reprezentujących 99,757\% całości kwoty Funduszu (IMF, 2017b). Zmiany udziałów w kwocie i liczbie głosów w Funduszu ukazano w tabeli 2.

${ }^{8}$ Kongres USA zgodził się na przyjęcie „,2010 Quota and Voice Reforms” 18 grudnia 2015 roku. Głównym powodem długotrwałego blokowania reformy wzmacniającej reprezentację w Funduszu gospodarek wschodzących była kwestia przesunięcia 63 mld USD z funduszu kryzysowego MFW na jego konto ogólne. 
Dwadzieścia państw czlonkowskich MFW dysponujących największym udziałem kwocie oraz liczbą głosów w Radzie Wykonawczej MFW po wejściu w życie zmian wynikających

z 14. Ogólnego Przeglądu Kwoty (stan z 26 kwietnia 2017)

\begin{tabular}{|c|c|c|c|c|c|}
\hline \multirow{2}{*}{ Lp. } & \multirow{2}{*}{ Państwo } & \multicolumn{2}{|c|}{ Przydzial (kwota) } & \multicolumn{2}{|c|}{ Glosy } \\
\hline & & SDR (w mln) & (w \% całości) & liczba głosów & (w \% calości) \\
\hline 1. & Stany Zjednoczone & 82994,2 & 17,46 & 831406 & 16,53 \\
\hline 2. & Japonia & 30820,5 & 6,48 & 309669 & 6,16 \\
\hline 3. & Chiny & 30482,9 & 6,41 & 306293 & 6,09 \\
\hline 4. & Niemcy & 26634,4 & 5,60 & 267808 & 5,32 \\
\hline 5. & Francja & 20155,1 & 4,24 & 203015 & 4,04 \\
\hline 6. & Wielka Brytania & 20155,1 & 4,24 & 203015 & 4,04 \\
\hline 7. & Włochy & 15070,0 & 3,17 & 152164 & 3,02 \\
\hline 8. & Indie & 13114,4 & 2,76 & 132608 & 2,64 \\
\hline 9. & Rosja & 12903,7 & 2,71 & 130501 & 2,59 \\
\hline 10. & Brazylia & 11042,0 & 2,32 & 111884 & 2,22 \\
\hline 11. & Kanada & 11023,9 & 2,32 & 111703 & 2,22 \\
\hline 12. & Arabia Saudyjska & 9992,6 & 2,10 & 101370 & 2,02 \\
\hline 13. & Hiszpania & 9535,5 & 2,01 & 96819 & 1,92 \\
\hline 14. & Meksyk & 8912,7 & 1,87 & 90591 & 1,80 \\
\hline 15. & Holandia & 8736,5 & 1,84 & 88829 & 1,77 \\
\hline 16. & Korea Płd. & 8582,7 & 1,81 & 87291 & 1,74 \\
\hline 17. & Australia & 6572,4 & 1,38 & 67188 & 1.34 \\
\hline 18. & Belgia & 6410,7 & 1,35 & 65571 & 1,30 \\
\hline 19. & Szwajcaria & 5771,1 & 1,21 & 59175 & 1,18 \\
\hline 20. & Indonezja & 4648,4 & 0,98 & 47948 & 0,95 \\
\hline $\begin{array}{l}\text { Całoś } \\
\text { by gł }\end{array}$ & $\begin{array}{l}\text { ć ogólnej kwoty SDR/licz- } \\
\text { sów w MFW }\end{array}$ & 475383,0 & 100,00 & 5030526 & 100,00 \\
\hline
\end{tabular}

Źródło: Opracowanie własne na podstawie IMF (2017a), IMF Members' Quotas and Voting Power, and IMF Board of Governors, 26 April, http://www.imf.org/external/np/sec/memdir/members.aspx, 26.04.2017.

Analiza wyników ,2 2010 Voice and Quota reform” dokonanych w wyniku przeprowadzenia 14. Ogólnego Przeglądu Kwoty prowadzi do kilku wniosków.

Po pierwsze, trudno uznać, że reforma ma charakter przełomowy, skoro jeszcze przed wejściem w życie analizowanych zmian wyraźnie zasygnalizowano konieczność dalszych zmian mających usatysfakcjonować państwa EMDC. W styczniu 2014 r. Rada Wykonawcza MFW przyjęła raport dotyczący 15. Ogólnego Przeglądu Kwot adresowany do Rady Gubernatorów - organu MFW odpowiedzialnego za podejmowanie kluczowych decyzji w Funduszu.

Po drugie, analiza ilościowa zmian udziału w kwocie i liczbie głosów wskazuje, że cele reformy zrealizowano tylko częściowo, a w niektórych przypadkach wręcz pozornie. Wśród siedmiu państw z grupy EMDC, które znalazły się w gronie dwudziestu największych udziałowców MFW, zdecydowanie zyskały jedynie Chiny, w znacznie mniejszym zaś stopniu Indie, Brazylia i Meksyk (tab. 3). 
Tabela 3

Udział w kwocie oraz liczba głosów w Radzie Wykonawczej MFW wybranych gospodarek wschodzących po zmianach z 2008 i 2010 roku

\begin{tabular}{|l|c|c|c|c||}
\hline \multirow{3}{*}{ Państwo } & \multicolumn{2}{|c|}{$\begin{array}{c}\text { 2008 Quota and Voice Reforms } \\
\text { (stan na 3.03.2011 r.) }\end{array}$} & \multicolumn{2}{c|}{$\begin{array}{c}\mathbf{2 0 1 0} \text { Quota and Voice Reforms } \\
\text { (stan na 26.04.2017 r.) }\end{array}$} \\
\cline { 2 - 5 } & $\begin{array}{c}\text { kwota } \\
\text { (w \% calości) }\end{array}$ & $\begin{array}{c}\text { liczba głosów } \\
\text { (w \% calości) }\end{array}$ & $\begin{array}{c}\text { kwota } \\
\text { (w \% calości) }\end{array}$ & $\begin{array}{c}\text { liczba glosów } \\
\text { (w \% calości) }\end{array}$ \\
\hline Arabia Saudyjska & 2,92 & 2,79 & 2,10 & 2,02 \\
\hline Brazylia & 1,78 & 1,71 & 2,32 & 2,22 \\
\hline Chiny & 3,99 & 3,80 & 6,41 & 6,09 \\
\hline Indie & 2,44 & 2,33 & 2,76 & 2,64 \\
\hline Indonezja & 0,87 & 0,85 & 0,98 & 0,95 \\
\hline Meksyk & 1,52 & 1,46 & 1,87 & 1,80 \\
\hline Rosja & 2,49 & 2,38 & 2,71 & 2,59 \\
\hline \hline
\end{tabular}

Źródło: Opracowanie własne na podstawie IMF (2011b).

Poza czterema wymienionymi wyżej państwami EMDC zyski pozostałych są relatywnie niewielkie (Indonezja) lub państwa te ponoszą straty (Arabia Saudyjska, Rosja). Wielkim przegranym reform jest Arabia Saudyjska, której udział w kwocie po reformie z 2010 r. zmniejszył się o 0,82 pkt proc., zaś liczby głosów o 0,77 pkt proc. Biorąc pod uwagę, że państwo to także w reformie z 2008 utraciło swój udział w kwocie o 0,34 pkt proc., a liczbę głosów, którymi dysponowało pomniejszono o 0,42 pkt proc. (por. tabela 1), udział Arabii Saudyjskiej w kapitale Funduszu w latach 2011-2017 obniżył się o 1,16 pkt proc., zaś liczba głosów, którym dysponuje spadła o 1,19 pkt proc. Jedynie pozornym beneficjentem reformy ,, 2010 Quota and Voice” została Rosja. Pomimo przyrostu udziału w kwocie ( $+0,22$ pkt proc.) i liczbie głosów $(+0,21$ pkt proc.) po reformie z 2010 roku, państwo to znalazło się po stronie przegranych bowiem we wcześniejszej reformie z 2008 r. jego udział w kapitale zakładowym Funduszu zmniejszył się o 0,29 pkt proc., zaś liczba głosów spadła o 0,35 pkt proc. liczby głosów (por. tabela 1). W rezultacie udział Rosji w kwocie w latach 2011-2017 zmniejszył się o 0,07 pkt proc., natomiast jej siła głosu stopniała o 0,14 pkt proc. Ta z konieczności ograniczona analiza prowadzi do wniosku, że jedynie część z państw EMDC odniosła rzeczywiste korzyści z reform zapoczątkowanych przez wspomniany pakiet singapurski. Pozostałe stały się „sponsorami” zmian. Poniesione przez te państwa straty zostały wyzyskane przez państwa rozwinięte wchodzące w skład klubów G7 i OECD, a także najbardziej wpływowe rynki wschodzące (Chiny, Indie, Brazylia, Meksyk).

Po trzecie, zmiany, do których doprowadziły ,Quota and Vote Reforms” z 2008 i 2010 r., wpłynęły na zwiększenie się różnicy w sile decyzyjnej między Chinami a pozostałymi państwami niedoreprezentowanymi w Funduszu, w stosunku do stanu poprzedzającego pakiet singapurski. Pekin w latach 2011-2017 powiększył udział w kapitale zakładowym Funduszu o 2,42 pkt proc. oraz liczbę głosów o 2,29 pkt proc. Pomimo to siła decyzyjna Chin oraz innych państw EMDC w MFW jest szokująco niska w stosunku do ich udziałów w gospodarce światowej, mierzonych na bazie PKB opartego na parytecie siły nabywczej (PPP). Dla przykładu udział Chin (18,41\%) jest wyższy niż USA (15,33\%). Jednakże to Stany Zjednoczone Ameryki posiadają 2,7 razy więcej głosów w MFW. Udział Indii w gospodarce światowej oparty na PKB (PPP) utrzymuje się na poziomie 7,49\%, 
a zatem znacznie przewyższa udział Włoch wynoszący 1,82\%. W MFW to jednak Włochy posiadają wciąż więcej głosów (3,02\% całości) niż Indie (2,64\%) (IMF, 2017c).

Tabela 4

Najbardziej niedoreprezentowani członkowie MFW w odniesieniu do ich udziału w gospodarce światowej (mierzonego w PKB PPP)

\begin{tabular}{|l|c|c||}
\hline \multicolumn{1}{|c|}{ Państwo } & $\begin{array}{c}\text { Liczba glosów w \% calości } \\
\text { (stan na 26.04.2017 r.) }\end{array}$ & $\begin{array}{c}\text { Udzial w gospodarce } \\
\text { światowej (PKB PPP) }\end{array}$ \\
\hline Chiny & 6,09 & 18,41 \\
\hline Indie & 2,64 & 7,49 \\
\hline Rosja & 2,59 & 3,11 \\
\hline Brazylia & 2,22 & 2,54 \\
\hline Indonezja & 0,95 & 2,57 \\
\hline Iran & 0,74 & 1,21 \\
\hline Turcja & 0,96 & 1,64 \\
\hline
\end{tabular}

Źródło: Opracowanie własne na podstawie IMF (2017c).

Po czwarte, zmiany wprowadzone „nowelami” z 2008 i 2010 roku niewiele zmieniły w rozkładzie siły decyzyjnej między blokiem wysokorozwiniętych państw Zachodu a państwami EMDC i najsłabiej rozwiniętymi (least developed countries - LDC). Na czele pierwszej z grup niezagrożoną pozycję zachował ,august” w MFW, którym są Stany Zjednoczone Ameryki. Dzięki udziałowi w kapitale zakładowym Funduszu wynoszącym $17,46 \%$, a także liczbie głosów (16,53\%) Waszyngton zarezerwował sobie prawo weta w organizacji, która do podjęcia decyzji o jakichkolwiek zmianach w statucie potrzebuje większości 3/5 państw członkowskich reprezentujących 85\% głosów. Pomimo kolejnych reform Funduszu redystrybuujących siłę decyzyjną w tej organizacji USA mogą liczyć na wsparcie ze strony „cezara” (UE-28), który jako młodszy kolega i współrządca Funduszu dysponuje 30,2\% udziału w kwocie Funduszu i pulą 29,4\% głosów. Nie koniec na tym, państwa zachodnie występujące jako klub G-7 posiadają 43\% udziału w kwocie i 41,2\% głosów, zaś liczba głosów członków OECD przekracza 63\% (choć znajduje się w tej grupie kilka państw o średnim dochodzie takich jak Meksyk czy Polska).

Wykres 3. Podzial kwoty między państwami rozwiniętymi i rozwijającymi się w MFW po wejściu w życie reform 2008 i 2010 Quota and Voice (w \% całości)

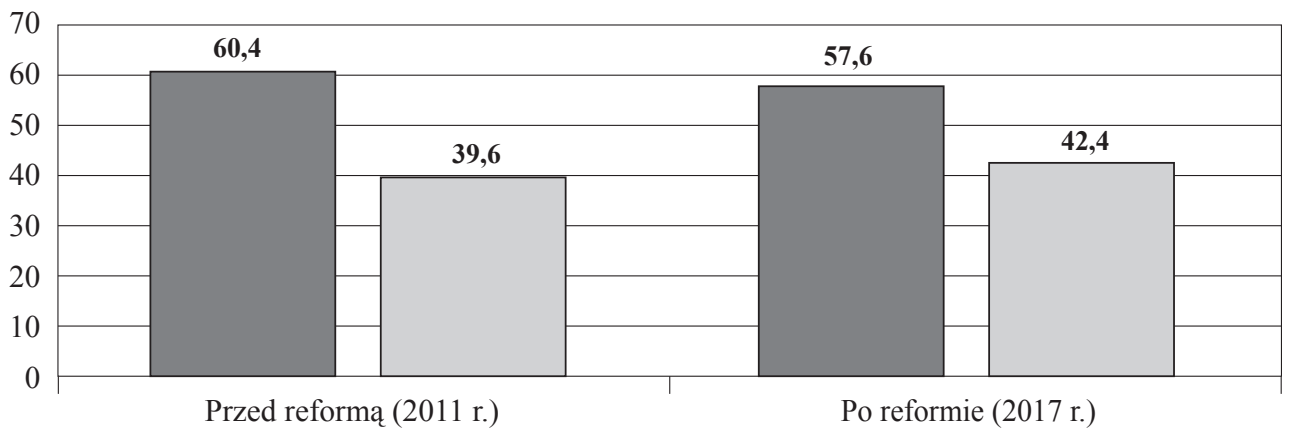

Państwa rozwinięte $\square$ Państwa rozwijające się

Źródło: Opracowanie własne na podstawie: IMF (2011b). 
Wykres 4. Podzial głosów między państwami rozwiniętymi i rozwijającymi się w MFW po wejściu w życie reform 2008 i 2010 Quota and Voice (w \% całości)

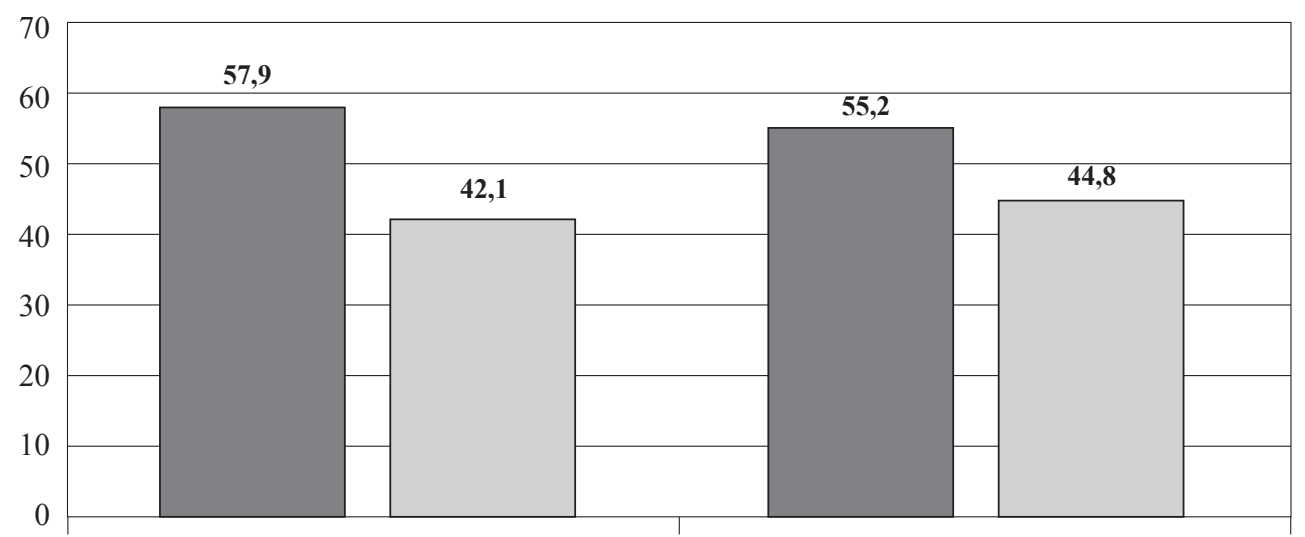

Przed reformą (2011 r.)

Po reformie (2017 r.)

Państwa rozwinięte $\square$ Państwa rozwijające się

Źródło: Opracowanie własne na podstawie: IMF (2011b).

Biorąc zatem pod uwagę efekty ostatniej odsłony reformy „Quota and Voice Reforms" argument o przełomowym znaczeniu zmian dla modelu funkcjonowania MFW nie wytrzymuje krytyki. Jak wynika z wykresów 3 i 4, transfer siły decyzyjnej z państw rozwiniętych do państw rozwijających się jest nieznaczny i nie odpowiada udziałowi gospodarek tych ostatnich $\mathrm{w}$ gospodarce światowej. Kolejną próbą pogodzenia racji państw nad- i niedoreprezentowanych w Funduszu będzie zapewne 15. Ogólny Przegląd Kwoty. Ze względu na posiadanie prawa weta przez USA oraz omnipotencję Departamentu Skarbu trudno jednak nawet w przybliżeniu wskazywać, kiedy nastąpi kolejna redystrybucja udziału w kwocie i liczby głosów w Funduszu.

\section{Wnioski}

Przeprowadzona analiza, osadzona w perspektywie krytycznej międzynarodowej ekonomii politycznej, pozwala na wyciagnięcie kilku wniosków. Daje się zauważyć, że kolejne odsłony reformy modelu funkcjonowania Funduszu, nie przyniosły spodziewanych rezultatów. Podejmowanie decyzji w tej organizacji jest poważnie zaburzone przez supremację kwotowo-głosową USA, wspieranych przez sojuszników z G-7 i OECD. MFW jest traktowany przez Waszyngton instrumentalnie jako jedna ze struktur, dzięki której możliwe jest utrzymanie pozycji lidera w globalnym zarządzaniu ekonomicznym. Nie dziwi zatem, że w czasie turbulencji finansowych wywołanych przez kryzys 2008+ większość decyzji Funduszu nie odzwierciedlała interesów niedoreprezentowanej większości i zawierała niekorzystne dla nich rozwiązania dedykowane procyklicznej polityce fiskalnej, polityce monetarnej lub kombinacji obu (policy mix) (Weisbrot i inni, 2009; Działo, 2012). Niska otwartość Funduszu na zmiany powoduje, że podobnie jak 
WTO, organizacja ta traci wiarygodność i znaczenie wśród stanowiących jej większość państw o niskim i średnim dochodzie narodowym brutto. Niektóre z nich deklarują, że korzystniejsze jest ograniczanie wydatków, przeciwdziałanie nadmiernemu zwiększaniu deficytu budżetowego i akumulacja rezerw na czas kryzysu, niż wystawianie się na konieczność pożyczania z MFW. Za wyjściem z tej ścieżki zależności optują przede wszystkim Chiny. Korzystając z nagromadzonych przez lata rezerw kapitałowych stały się alternatywnym źródłem zasobów pożyczkowych i walut poprzez inwestycje oraz pomoc zagraniczną. Trend ku poszukiwaniu alternatywnych opcji pożyczkowych wobec instrumentów oferowanych przez MFW objawia się też tworzeniem konkurencyjnych wobec Funduszu instytucji takich jak Azjatycki Bank Inwestycji Infrastrukturalnych (Asian Infrastructure Investment Bank, AIIB), działającej od 2016 roku międzynarodowej instytucji finansowej skupiającej się na wspieraniu budowy infrastruktury w regionie Azji i Pacyfiku. Do innych tego typu rozwiązań można zaliczyć Nowy Bank Rozwoju oraz Porozumienie o stworzeniu rezerwy środków finansowych na wypadek pojawienia się sytuacji kryzysowych (Credit Reserve Arrangement - CRA). Ostatnia z wymienionych instytucji, stworzona przez państwa BRICS w lipcu 2014 r. i uruchomiona rok później, po zakończeniu procedury ratyfikacyjnej, stanowi „alternatywny obwód” stanowiący wyzwanie dla przeciążonej sieci finansowej MFW, a jednocześnie szansę dla państw EMDC na dostarczenie płynności w przypadku rzeczywistego lub potencjalnego problemu z równowagą bilansu płatniczego. Realizację tego celu, jakże zbliżonego do celu MFW, zapewniają rezerwy w wysokości 100 mld USD zadeklarowane przez państwa BRICS gotowe do uruchomienia linii swapowej.

W świetle wyłaniania się alternatywnych ośrodków zapewnienia płynności mało elastyczny MFW będzie najprawdopodobniej w dalszym ciagu tracić znaczenie jako „pożyczkodawca ostatniej szansy” dla państw rozwijających się, choć trudno wyrokować w jakim tempie proces degradacji wpływów Funduszu będzie następował. Ocena kolejnych przeglądów kwot wskazuje, że MFW upodobnia się do Światowej Organizacji Handlu, która po kolejnych rundach rokowań handlowych dotarła do punktu, gdzie o konsensus niezmiernie trudno. Mowa tutaj o kwestii braku zgody odnośnie do handlu produktami rolnymi. W przypadku MFW granica, której przekroczenie wydaje się mało realne jest utrata przez USA większości pozwalającej blokować temu państwu niekorzystne dla siebie postanowienia i traktować Fundusz jako strukturę, dzięki której możliwe jest utrzymanie pozycji lidera w globalnym zarządzaniu ekonomicznym. Pomiędzy WTO a MFW podobieństw jest więcej. Obie organizacje pojawiły się w okresie drugiej fali globalizacji i jako takie są przestarzałymi, ,skorodowanymi urządzeniami”, które słabo radzą sobie z wyzwaniami ery usieciowania bez mała wszystkiego. Ich niskiej efektywności w obszarze zarządzania handlowego i finansowego towarzyszy odradzanie się tendencji protekcjonistycznych, a także bilateralizacja relacji handlowych i finansowych między państwami. Cechą wszakże odróżniającą WTO i MFW jest to, że w pierwszej ze wskazanych instytucji państwa rozwijające się potrafiły z sukcesem rzucić wyzwanie państwom rozwiniętym i to w wielu dziedzinach, np. w zakresie polityki zdrowia publicznego, leków generycznych, polityki rozwoju. Ich siłą stała się zasada podejmowania decyzji w oparciu o konsensus oraz system rozstrzygania sporów między państwami członkowskimi tej organizacji. Odmienna sytuacja zachodzi w MFW. Członkowie Funduszu nie są w stanie zakwestionować prymatu G-7. Państwa rozwijające 
się nie tworzą w MFW bloków i koalicji nacisku współdziałając z NGO-sami, a dialog i deliberację zastępuje dyktat państw posiadających przewagę w Radzie Wykonawczej. Petryfikacja takiego stanu rzeczy pomimo kolejnych „reform” nie służy Funduszowi, który coraz częściej traktowany jest raczej jako techniczna organizacja znajdująca się w orbicie oddziaływania G-20, niż samodzielny podmiot uważany za wiarygodnego partnera przez 189 państw członkowskich. Być może na przełomowe reformy MFW jest za późno, a sam Fundusz powoli zmienia się w organizację typu „zombie” - strukturę formalnie wciąż działająca, choć pozbawioną możliwości realizacji swoich celów statutowych. O ile obecnie jest stanowczo za wcześnie by MFW jednoznacznie charakteryzować w ten sposób, w przypadku kolejnych „pozornych przełomów” i rozwijania alternatywnych wobec niego międzynarodowych instytucji finansowych przez aktorów spoza świata zachodniego, postawienie takiej hipotezy może być w pełni uzasadnione.

\section{Bibliografia}

BRICS (2014a), Treaty for the Establishment of a BRICS Contingent Reserve Arrangement, July 15.

Fortaleza, Brazil, http://www.brics.utoronto.ca/docs/140715-treaty.html, 10.10.2016.

BRICS (2014b), Agreement on the New Development Bank, July 15, Fortaleza, Brazil, http://www. brics.utoronto.ca/docs/140715-bank.html, 10.10.2016.

Cox R. W., Jacobson H. K. (1973), The Anatomy of Influence: Decision Making in International Organization, Yale University Press, New Heaven.

Cox R. W., Sinclair T. J. (1996), Approaches to World Order, Cambridge University Press, Cambridge.

Działo J. (2012), Dlaczego trudno jest prowadzić ,,dobra” polityke fiskalna, „Gospodarka Narodowa”, nr 1-2 (245-246), Rok LXXX/XXI.

Fin24 (2012), BRICS agree to boost IMF war chest, 19.06.2012, http://www.fin24.com/Economy/ Brics-agree-to-boost-IMF-war-chest-20120619, 7.09.2016.

Haibin N. (2012), BRICS in Global Governance: A Progressive Force? Dialogue on Globalisation, Friedrich Ebert Stiftung, New York.

IMF (2006), IMF Board of Governors Approves Quota and Related Governance Reforms, September 18, Press Release no. 06/205, http://www.imf.org/external/np/sec/pr/2006/pr06205.htm, 10.10.2016.

IMF (2008), Reform of IMF Quotas and Voice: Responding to Changes in the Global Economy, IMF Issues Brief, April, Issue 1, https://www.imf.org/external/np/exr/ib/2008/040108.htm, 10.02.2017.

IMF (2010a), IMF Executive Board agrees major overhaul of quotas and governance, Press Release no. 10/418, November 5, http://www.imf.org/en/News/Articles/2015/09/14/01/49/pr10418, 10.02.2017.

IMF (2010b), IMF Quota and Governance Reform - Elements of an Agreement, IMF Policy Paper, October 31, Washington D.C.

IMF (2011a), The IMF's 2008 Quota and Voice Reforms Take Effect, Press Release March 3, Press Release no. 11/64, March 3, http://www.imf.org/external/np/sec/pr/2011/pr1164.htm\#P18_387, 23.04.2017.

IMF (2011b), Quota and Voting Shares Before and After Implementation of Reforms Agreed in 2008 and 2010, Washington D.C., http://www.imf.org/external/np/sec/pr/2011/pdfs/quota_tbl.pdf, 23.04.2017. 
IMF (2015), IMF Managing Director Christine Lagarde Welcomes U.S. Congressional Approval of the 2010 Quota and Governance Reforms, Press Relaease, no. 15/573, December 18, Washington D.C., http://www.imf.org/external/np/sec/pr/2015/pr15573.htm, 23.04.2017.

IMF (2016a), Articles of Agreement of the International Monetary Fund, April, Washington DC, 14.02.2017.

IMF (2016b), IMF Quotas, IMF Factsheet 2016, https://www.imf.org/About/Factsheets/ Sheets/2016/07/14/12/21/IMF-Quotas?pdf=1, 14.02.2017.

IMF (2016c), World Economic Outlook Database, World Economic and Financial Surveys, April, https://www.imf.org/external/pubs/ft/weo/2016/01/weodata/index.aspx, 14.02.2017.

IMF (2017a), IMF Members' Quotas and Voting Power, and IMF Board of Governors, 26 April, http:// www.imf.org/external/np/sec/memdir/members.aspx, 26.04.2017.

IMF (2017b), Acceptances of the Proposed Amendment of the Articles of Agreement on Reform of the Executive Board and Consents to 2010 Quota Increase, 24 April, http://www.imf.org/external/ $\mathrm{np} / \mathrm{sec} / \mathrm{misc} / \mathrm{consents.htm,} \mathrm{26.04.2017.}$

IMF (2017c), GDP based on PPP, share of world, World Economic Outlook, April 2017, IMF Data Mapper, http://www.imf.org/external/datamapper/PPPSH@WEO/OEMDC/ADVEC/WEOWORLD/WEQ, 26.04.2017.

Kahn J. (2000), I.M.F. Directors Fail to Rally Around Any New Leader in Poll, „The New York Times”, 3.03.2000, http://www.nytimes.com/2000/03/03/business/imf-directors-fail-to-rally-aroundany-new-leader-in-poll.html, 2.03.2017.

Keohane R. O. (1984), After Hegemony: Cooperation and Discord in the World Political Economy, Princeton University Press, New York.

Larionova M., Shelepov A. (2015), Is BRICS Institutionalization Enhancing Its Effectiveness?, w: The European Union and The BRICS. Complex Relations in the Era of Global Governance, red. M. Rewizorski, Springer, Heidelberg-New York.

Lukov V. (2012), A Global Forum for the New Generation: The Role of the BRICS and the Prospects for the Future, http://www.brics.utoronto.ca/analysis/Lukov-Global-Forum.html, 20.10.2016.

Menkes M. (2010), IMF's Governance Reform in the Shadow of Current-accounts Balance Debate, PISM, Bulletin, no. 131 (207).

MercoPress (2009), South American leaders sign agreement creating South Bank, 27 September 2009, http://en.mercopress.com/2009/09/27/south-american-leaders-sign-agreement-creating-southbankBrazilian, 23.10.2016

Peterson, S. V. (2003), A Critical Re-Writing of Global Political Economy: Integrating reproductive, productive and virtual economies, Routledge, London.

Rewizorski M. (2015), Participation of the European Union and the BRICS in the G-20, w: The European Union and The BRICS. Complex Relations in the Era of Global Governance, red. M. Rewizorski, Springer, Heidelberg-New York.

Sinclair T. J. (2012), Global Governance, Polity Press, Cambridge.

Strange S. (1970), International Relations and International Economics: A Case of Mutual Neglect, „International Affairs”, vol. 46, no. 2.

Weisbrot M., Ray R., Johnston J., Cordero J. A., Montecino J. A. (2009), IMF - Supported Macroeconomic Policies and the World Recession: A Look at Forty-One Borrowing Countries, Center for Economic and Policy Research, Washington, DC, http://cepr.net/publications/reports/imfsupported-macroeconomic-policies-and-the-world-recession, 2.03.2017.

Woods N. (2010), Global Governance after the Financial Crisis: A New Multilateralism or the Last Gasp of the Great Powers?, „Global Policy”, vol. 1, issue 1.

Wróblewski M. (2016), Międzynarodowy Fundusz Walutowy w systemie globalnego zarzadzania - ewolucja modelu działania?, w: Globalne zarzadzanie i jego aktorzy. W poszukiwaniu rozwiqzań dla zmieniającego się świata, red. M. Rewizorski, Elipsa, Warszawa. 
Xing L. (2014), Introduction. Understanding the Hegemony and the Dialectics of the Emerging World Order, w: The BRICS and Beyond. The International Political Economy of Emergence of a New World Order, red. Li Xing, Ashgate, Farnham.

\title{
Much Ado About Nothing? Comments on Reform of the Functioning Model of the International Monetary Fund
}

\begin{abstract}
Summary
The main objective of this article is to analyze the effects of transformation of the IMF working model, launched in 2006, accelerated since 2010, and identified as the most fundamental governance overhaul in the Fund's 65-year history and the biggest ever shift of influence in favor of emerging market and developing countries to recognize their growing role in the global economy. This article, set within the institutional framework of global governance and critical international political economy, attempts to clarify whether the IMF reform focused on modifying the size of member countries' participation in the share capital of the Fund, resulted in significant increase of voting power of emerging markets and developing states or rather was example of global economic governance dysfunctionality.
\end{abstract}

Key words: International Monetary Fund, global governance, emerging economies, quota 
